The Teaching Materials Series helps to document Allen's activities as a professor at New York University and as a lecturer at Nagano, Japan, in 1955, where one of his fellow lecturers was Nobel laureate William Faulkner. The Series includes Japanese newspaper clippings about Faulkner as well as Allen's notes about him.

The Walt Whitman Materials Series contains various materials related to Allen's research on Whitman. The Commemorations and Societies Subseries and the Popular Culture Subseries document the ever increasing interest in Whitman's life and works during the twentieth century. The Correspondence Subseries and Pictures Subseries contain copies of letters and pictures relating to Whitman and his age; the Writings Subseries contains copies of Whitman's poems and prose.

The Walt Whitman Scholars Series contains papers of six Walt Whitman scholars. It suggests the international range both of Whitman scholarship and of Allen's interests. In addition to the interest in Whitman she shared with her husband, Evie Allison Allen was also a skilled translator of Germanic languages. Charles N. Elliot and Emory Holloway, as well as Canadian Henry Scholey Saunders, were Whitman collector-scholars who interacted with both Allen and Furness. The late Peter Mitilineos was one of Allen's students and was particularly interested in the writings of Italian Whitman scholar Pasquale Jannacone. The writings of German Whitman scholar Hans Reisiger were an interest of both Professor and Mrs. Allen.

The Writings Series contains not only copies of Allen's many essays and book reviews but also the various drafts and production stages of several of his books.

Additional information about the Allen Papers and the Hubbell Center may be obtained by writing or calling The Jay B. Hubbell Center, Special Collections Library, Duke University, Box 90185, Durham, North Carolina 27708-0185; phone 919-660-5820; fax 919-684-2855.

Fames Madison University

STANLEy S. BLAIR

\title{
DEMOCRACY IN ACTION:
}

\section{NAMING THE BRIDGE FOR WALT WHITMAN}

Resolved: That, in accordance with the recommendations of the Special Committee on Bridge Names, designation of the present Delaware River Bridge be changed to the "Benjamin Franklin Bridge," and

Be It Further Resolved: That, in accordance with the recommendations of the Special Committee on Bridge Names, designation of the Packer Avenue-Gloucester City Bridge be the "Walt Whitman Bridge. ...."

And so on June 16, 1954, the Delaware River Port Authority Special Committee on Bridge Names voted unanimously to rename the bridge already in existence and to name a second bridge soon to be built in honor of two American heroes. ${ }^{1}$ But still to be heard were other voices as a remarkable campaign developed which is best viewed as an instance of democracy in America, though turned against democracy's very champion, Walt Whitman. 
The resolution was passed just as the literary world was preparing to celebrate in the next year the centenary of the first publication of Leaves of Grass. That year would bring the definitive Whitman biography, Gay Wilson Allen's The Solitary Singer, a major critical reconsideration from Richard Chase, a catalog of the Whitman Collection in the Library of Congress, scholarly conferences in many countries, and a general acknowledgment of Whitman's achievement as "the poet of Democracy." But while much of the world was engaged with these commemorative events, New Jersey-the state where Whitman died and was buried-engaged in a democratic exercise that could only have made the poet chortle with delight, had he known of it, and especially if he had known the outcome.

It all began simply enough, with a letter from the vice president of The Franklin Institute in Philadelphia requesting that the Delaware River Bridge be renamed for Philadelphia's favorite son in honor of the 250th anniversary of his birth in 1956. While the Authority had no objection to the request, it raised the issue of a suitable name for the second bridge which was expected to be completed by 1957 . Accordingly, the Special Committee was appointed which set the standards for bridge names: that historic names be confined to those commanding ready public recognition and acceptance; that if a historic personage was chosen for one bridge, the second bridge should also bear the name of a historic person; and that the names should reflect equal prestige upon the two states, New Jersey and Pennsylvania. The choice of Benjamin Franklin for the existing bridge was a "natural" for the Committee, but was there someone who compared with him for the structure then known as the Packer AvenueGloucester City Bridge? Among the possibilities considered were Betsy Ross, who was married in Gloucester but already had a house named for her in Philadelphia; William Penn, who already had a state named for him; and Woodrow Wilson, whose only connection with New Jersey was as president of Princeton University. Five New Jersey signers of the Declaration of Independence had slipped so deep into obscurity that they did not meet the criterion of public recognition. By a process of elimination the Committee settled on Walt Whitman, and on July 20, 1955, the bridges were named and a pamphlet issued to inform the public.

In fact, the public had already involved itself somewhat in the process. As early as the spring of 1954, the Philadelphia Inquirer had run a story on "The Bridge Without a Name," referring to the planned Bridge \#2 at Packer Avenue. ${ }^{2} \mathrm{~A}$ few individuals had offered suggestions either of compound names that emphasized the link between New Jersey and Pennsylvania, or names of historic persons, such as Thomas Jefferson, John Barry, Thomas Paine, Betsy Ross, and Thomas Edison. An idealistic youngster wanted to call it "Brotherhood Bridge," and the Pennsylvania chapter of American Gold Star Mothers, Inc. wrote requesting the bridge be called "Penn-Jersey Memorial Bridge" in honor of the war dead of both states who served in World War II and in Korea. Later the Inquirer reported that the bridge would honor the hundredth anniversary of Leaves of Grass. No immediate response was forthcoming, but toward the end of 1955, after the bridge had been named and after the celebrations of Leaves had been held throughout the world, a letter was sent to the Port Authority asking for a reconsideration of the name because, the letter 
writers claimed, Whitman did not have the "noble stature" required for such an honor, and "his life and works are personally objectionable to us." The letter, dated December 16, was signed by the Reverend Edward Lucitt, Diocesan Director of the Holy Name Union of the Diocese of Camden, Monsignor Joseph McIntyre, and seven leaders of Holy Name Societies in southern New Jersey.

What had stirred the clergymen to this action was a series of articles that appeared in the Camden diocesan weekly newspaper written by the pastor of a Westville, New Jersey church. In these articles, Rev. James Ryan assumed the mantle of both literary critic and moralist, claiming Whitman was of no consequence as a poet and professing to be scandalized by both his personal morals and political views. The New York Times jumped on the story with the angle that Roman Catholics had begun a campaign against Walt Whitman. The Times story included a bit of information that indicated Rev. Lucitt had done some research among the recent publications on Whitman; pressed to be specific on what it was he objected to about the poet, Father Lucitt referred to Gay Wilson Allen's biography, claiming that Allen had concluded Whitman was "homosexual." Allen corrected this, pointing out that he had used the word "homoerotic," since he had found no evidence of homosexuality. ${ }^{3}$ It is doubtful, however, that this fine distinction had much of an impact on the Holy Name Societies.

Catholic newspapers and periodicals picked up on the growing controversy and various clergymen were quoted to the effect that Walt Whitman really belonged elsewhere, to Long Island or New York City, that only illness had brought him to New Jersey, that he was not a poet worthy of the honor of a bridge named for him, and, most damning of all, that he was not a believer. Some turned to the poetry and found there such objectionable passages as Section 32 of "Song of Myself" where the poet extols animals for their lack of religiosity ("They do not make me sick discussing their duty to God"). Then there were the outcries of protest, from clergy and laity, at Whitman's praise for the common man, a level of praise which, it was claimed, should only be directed to deity. Someone read enough of Leaves (at least "Passage to India") to find that Whitman considered himself to be "the true son of God." Cold War politics also entered the picture, with some objectors claiming that Whitman was more highly regarded by the Chinese Communists than by United States citizens. Father Ryan, the first of the clergymen/critics on the case, however, had chosen to refer to "As I Lay With My Head in Your Lap Camerado" to illustrate his point that the poet, in denying the validity of the threat of hell and the lure of heaven, had proven himself in contempt of religious principles. This notion was later amplified and made to seem truly threatening.

A slight rebuff of the New Jersey Catholics involved in the protest came from an editorial in The Ave Maria, a Catholic Home Weekly published at Notre Dame, Indiana. After briefly recapping the controversy, the editorial warned against the folly of using the weight of a Catholic group voice in "less important matters" (less important than the showing of "obscene movies" or "legislation authorizing the distribution of birth control literature"). "We also believe Father Lucitt is on questionable ground," the editor continued, "in 
challenging the stature of Whitman's work and the respectability of his life. Scholars and historians have never shown that the 'homoeroticism' of his poetry was a reflection of an immoral life." 4

But calls to reason such as this had no effect on the defenders of public morals and political ideals. Their next move was to fire a salvo of mimeographed form letters addressed to the Executive Director of the Port Authority and requesting a change of name for the bridge. The letters all bore the date January 1956, and many included as the place of origin Delaware Valley, U.S.A. A number carried multiple signatures, but the nuns living in a convent on Church Street in Camden signed their names to individual copies of the letter. Some people (among them at least one Mickle Street resident) signed more than one copy, and some signers identified themselves as members of the Holy Name Society or of the Knights of Columbus. The letters came principally from Camden, Pennsauken, Mt. Ephraim, Hilltop, and Blackwood, all southern New Jersey communities. A heavy concentration of signatures from individuals living on Stevens Street and Mickle Street indicates a targeted canvassing of these two streets where Whitman had lived. The envelopes in which the form letters arrived were hand written, whole batches of them by the same hand, indicating an organized effort, although the organization or organizations were never identified.

By January 27, 1956, 467 mimeographed form letters opposing the name of Walt Whitman had been received; in addition there were 29 individually written letters in opposition, 49 letters supporting the choice of name, and 24 letters opposing and/or suggesting an alternative name. ${ }^{5}$ Among the nominations for a new name were the familiar ones-William Penn, Woodrow Wilson, Thomas Jefferson, Betsy Ross, Thomas Paine-and a new one, Joyce Kilmer, proffered by a small number of individuals who deemed him a worthier poet than Whitman, mainly, according to their letters, on the basis of his having been a native of New Jersey, a World War I hero, and a Christian. Some of these letter writers proclaimed "Trees" a poem superior to any written by Whitman.

Though the tendency is to dismiss with little thought a campaign of form letters, it is worth noting precisely what the charges were that were raised against Whitman by the good citizens of southern New Jersey. Here then is the text of the letter:

\section{Delaware River Port Authority}

Bridge Plaza

Camden, New Jersey

\section{Gentlemen:}

We oppose the naming of the new $\$ 90,000,000$ bridge as a memorial to Walt Whitman for the following reasons:

(1) $\mathrm{He}$ is not great enough to deserve this honor. In what way has he inspired or influenced American democracy for good?

(2) He boasted of his immoralities and published immorality as a personal experience.

(3) He held Christianity in contempt, and affirmed himself as the new savior of mankind.

(4) He attempted to teach rebellion against the natural law of God, and the right order established by the tortured experience of the centuries. 
(5) His political philosophy, dusted off the scrap heap during the depression, as the Voice of the Common Man, has proved alien to Jeffersonian Democracy, and he is now the Poet Laureate of the World Communist Revolution.

Because the naming of the Bridge in his honor would raise him to the status of a national hero, give aid and comfort to the enemies of our established order of morality and democracy, make the teaching of religious concepts difficult, and bring the common stamp of morality on our heritage into contempt, we ask you to drop Whitman's name from the Bridge.

One cannot fail to notice the immediate reference to the cost of the bridge, which was carefully calculated to arouse a taxpayer's interest in the text that follows. Of the five points given, the one that seems the most ambiguous and veiled in its meaning-and therefore the most intriguing - is point four. What exactly is meant by "the natural law of God"? The laws of Nature and of Nature's God are held in the highest regard in Whitman's poetry, as they were by all the Romantics, especially the Transcendentalists from whom Whitman took much of his impulse. There is no instance of his teaching "rebellion" against natural law, or "the right order," whatever that may be. Is this to be understood as a reference to right-wing political philosophy? And is this philosophy, or ideology, to be seen as having been arrived at as the result of "the tortured experience of the centuries" of human experience under other systems of philosophy and/or. governments? The concluding paragraph of the letter contains a reference to "our established order of morality and democracy," which may throw some light on point four, but even presuming that the "right order" equals "our established order of morality and democracy," how, precisely, does this connect to "the natural law of God"? We can only conclude that lurking behind this charge is a veiled reference to homosexuality, viewed as a form of rebellion against a "natural law" and "right order" of heterosexuality, and grounded perhaps in Father Ryan's carefully planted drawing of attention to "As I Lay With My Head in Your Lap Camerado." That this proclaimed "right" order should have been established by the "tortured experience of the centuries" says more perhaps about heterosexuality than the writers may have wished to convey, but one cannot expect precision of thought and language in a form letter, especially when, as here, it is attempting to send a coded message.

By the end of January 1956, the Office of the Attorney General of the Commonwealth of Pennsylvania began receiving inquiries concerning a proposed change in the name of the Walt Whitman Bridge. Most of these came from individuals in Philadelphia who were aware of the Camden campaign and opposed it either because they resented the interference of the Catholic Church or because they genuinely supported the choice of name. The latter group consisted mainly of educated people engaged in the professions and included Whitman scholar Sculley Bradley and Clinton Rossiter, professor of government and political science. Gertrude Traubel wrote on the letterhead of her father's organization, the Walt Whitman Fellowship International, and the Leader of the Philadelphia Ethical Society, another of Horace Traubel's interests, circulated a counter-petition seeking support of the Port Authority choice. More surprisingly, the Daughters of the American Revolution, Valley of the Delaware Chapter, wrote to support the naming, citing the principle of sepa- 
ration of church and state. A Connecticut resident saw in the controversy a single issue and wrote simply, "Michael Angelo was a homosexual. Why don't they destroy the Sistine chapel?"

A complete account of the affair, including the exact number of letters of support and of objection, was given to the Attorney General's office by the Port Authority, along with a firm denial that a change of name was being considered. The entire matter seems to have dropped from public attention at about that point, and the bridge remains the Walt Whitman Bridge. Evidence of the changing attitudes of changing times lies in the fact that only a decade later there was no objection raised when the New Jersey Turnpike Authority changed the name of one of its service areas, located in the southern part of the state, from the Cherry Hill Township Service Area to the Walt Whitman Service Area. (Services offered include a Roy Rogers Restaurant, a snack bar, and fuel and auto services. $)^{6}$

While we could look back on this small tempest with a mixture of annoyance and amusement, there is every reason to believe that Whitman would have seen in it some positive aspect of democratic action that allowed a variety of individuals to voice freely their opinions. But there is also reason to believe that he would have been very pleased that the Port Authority remained firm in its choice of name. Moved to poetic effort by speculation as to what his reaction would have been, one member of the Walt Whitman Birthplace Association on Long Island-where there had also been some objection to the preservation of the house where Whitman was born-produced the following "Letter to Walt Whitman":

Well, Camerado, I guess you heard, There was quite a tussle recently

In the Quaker City of Brotherly Love

About you and a bridge

Joining said city with the other city

Where you lived, talked, peddled your books, and died;

And where your memory is already somewhat perpetuated

by Walt Whitman Canned Tomatoes (a grade A line) and other choice groceries.

Your opposers were-the usual public inflicters of private morality

That you were long in life familiar with;

And you were accused of the usual perversions:

Bestiality, immorality, verselessness, and the corruption of kiddies.

Even another bard was puffed in your place-

Joyce Kilmer, for God's sake.

Whose leaves are less tall than your leaves, to all

But the shielded eye.

An old story, no doubt.

But the funny thing about this case, Camerado, was

That they lost.

And that sparkling, soaring, two-mile span of steel

Is all yours:

The Walt Whitman Bridge.

What do you dream of that, Walt?

Is it for real? 
1 Report of the Special Committee. This report, as well as most other materials cited are in the Special Collections, Van Pelt Library, University of Pennsylvania in a box labeled "Delaware River Port Authority: Walt Whitman Bridge."

2 Janice Rowan, "Walt Whitman and the Battle of the Bridge," unpublished paper presented for a seminar in American literature, University of Pennsylvania, December 19, 1964, 3.

3 “Catholics Decry Whitman Bridge," New York Times, December 17, 1955, 16.

4 "What's In A Name," The Ave Maria, \#83 (January 7, 1956), 3.

5 Letter to Deputy Attorney General from Delaware River Port Authority, January 27, 1956.

6 The name change was made in mid-November 1966. Information was provided by the New Jersey Turnpike Authority.

7 Paul C. Wermuth, "Letter to Walt Whitman," Walt Whitman Birthplace Bulletin 2 (April 1959). On the history of the Whitman Birthplace, see my "Walt Whitman in the Public Domain: A Tale of Two Houses," Long Island Historical fournal 6 (Fall 1993), 83-95. 